\title{
REASONABLE SEARCH AND RESEARCH
}

\section{JoHn Barker WAIte $\dagger$}

The originally audacious assertion that courts may properly base decision on an evaluation of utilities has become a platitude. Whether the judicial process be philosophically characterized as ascertainment of preexisting but previously unformulated law, as application of known law to novel facts, as reshaping of law, as making of law, or simply and frankly as declaration of choice between conflicting theories of social interest, the fact remains that in case after case decision has in truth depended upon judicial notions of wise public policy. ${ }^{1}$ In the phrasing of Mr. Justice Stone, "Strictly speaking, he [the judge] is often engaged not so much in extracting a rule of law from the precedents, as we were once accustomed to believe, as in making an appraisal and comparison of social values, the result of which may be of decisive weight in determining what rule he is to apply." 2

But if precedent be not the true basis of decision, what is? Something must be substituted for precedent as a guide; if decision be a matter of appraisal, courts must at least be equipped to appraise. With acceptance of Mr. Stone's assertion-and its truth is undeniable-we begin the breakdown of a socially sedative philosophy. Judicial decision ceases to be an ineluctable transcendentalism speaking through the judges; it is revealed as a very

† A.B., 1905, Yale University; LL. B., I907, University of Michigan; Professor of Law at the University of Michigan; author of PAtENT LAW (I920), LAW OF SALES (I92I), Cases on Criminal Law and Procedure (I93I), Criminal Law in Action (1934), and of articles in various periodicals.

I. E. g. If $A$ entrusts $B$ with possession and $B$ fraudulently sells to $C$, who buys in good faith, is it wise economic policy to protect $A$, or $C$ ? See Waite, Caveat Emptor and the Judicial Process (I925) 25 Coc. L. Rev. I29.

Is a contract whereby a manufacturer seeks to fix the resale price of his product contrary to public policy? See Waite, Public Policy and Persontal Opintion (I92I) I9 MrCE. L. REv. 265.

Does public policy require that a retailer of goods be held liable for unknown defects therein? See Waite, Retail Responsibility and Judicial Law Making (I936) 34 MICH. I. REV. 494.

Should landowners be required to fence cattle out, or cattle owners be required to fence them in? This is discussed as a matter of public policy in McKee v. Trisler, 3 II III. 536, I43 N. E. 69 (1924).

Should manufacturers be liable in tort to remote buyers of their goods? See MacPherson v. Buick Motor Co., 2I7 N. Y. 382, III N. E. IO50 (I9I6); of. the "policy" argument in Ultramares Corp. v. Touche, 255 N. Y. I70, I74 N. E. 44I (I93I). See also Jeanblanc, Manufacturers' Liability to Persons Other Than Their Immediate Vendees (I937) 24 VA. L. REv. I34, showing the effort of courts to rationalize policy with precedent.

Should a railroad be held liable to owners of destroyed houses other than the one on which its sparks fell? Note the contradictory ideas of "policy" in Ryan v. New York Central Ry., 35 N. Y. 210 (1866) and Hoyt v. Jeffers, 30 Mich. I8r (1874).

Does prohibition of the manufacture of cigars in tenement houses really conduce to better public health? Matter of Jacobs, $98 \mathrm{~N}$. Y. 98 (1885). Or the regulation of labor in bakeries really profit society? Lochner v. New York, 198 U.. S. 45 (I905).

2. See Stone, The Common Laze in the United States in THE Future of the Common LAW (Harvard Tercentenary Publications, 1936) I20, 127. 
human utterance based on individual ideas of what is wise. With denial of precedent as an all-sufficient indicator, we admit determination of public policy by judicial choice as really, despite its narrower limits, as we admit it by acts of the legislature. Yet legislation by legislatures presupposes study of fact: of the evils to be remedied, of the practical effect of one policy or another, of politico-socio-economic conditions and necessities. Legislatures have the advantage of publicity for what they propose to do, of criticism, of gratuitously offered information as to those facts. Legislating judges, however, labor without those advantages. Nevertheless, if their choices of public policy are to be wisely made, they must be made in the light of knowledge. Precedent, if it be not the determinant of decision, is no substitute for knowledge. "If we search the precedents so intent upon the past that we have no eye for what is going on in the world about us, it is easy to find analogies and resemblances which will serve as a superficial justification for the extension of a precedent to sets of facts whose social implications may be quite different from any which the precedents have considered." 3 In other words, if judicial decision is to be utilitarian it must comprehend the utilities. "Knowledge is essential to understanding and understanding should precede judging." 4 Should precede; but does it? Has the public given judges the help they need? When they, the judges, contemplate policies and select that which they prefer, do they in truth see the conditions under which their notions of public good must operate? Are they quite conversant with the social needs which they purport to satisfy? And if they are thus equipped to make their choice, whence comes that knowledge of conditions with which they supplement their learning in law? Is it the collated studies of others, or the narrower product of mere personal experience?

Upon one who studies judicial decisions, there is forced a certain rather distressing alternative of answers to these questions-far too frequently for public good, judges lay down a policy of social conduct either without comprehension of the conditions to which it relates, or else out of a comprehension based solely on their own empiricism. Illustrative decisions are plentiful. ${ }^{5}$ But let us take for example here the declarations of judicial choice in a single phase of that sempiternal conflict between social interest in effective enforcement of the criminal law and social desire for a minimum of police interference with the activity of individuals. One question of policy which the courts have had to determine is this: Under what conditions and to what extent may police officers, without a warrant, search for evidence of crime?

3. $I d$. at $\mathrm{1} 26$.

4. Burns Baking Co. v. Bryan, 264 U. S. 504, 520 (I924). See also the court's comment on its own lack of information in People v. Schweinler Press, 2I4 N. Y. 395, 4II, 108 N. E. 639,643 (I9I5).

5. See references cited supra note I. 
The problem is one of policy, not of law. Despite surprisingly prevalent belief to the contrary, neither state nor federal constitutions forbid search without a warrant. They prohibit only "unreasonable" searches and seizures. ${ }^{6}$ Nor do the constitutional provisions define unreasonable; precise application of the term is left to judicial decision-or at least judges have assumed the function of applying it. ${ }^{7}$ And, obviously, what is or is not reasonable must depend both on the immediate circumstances and, even more essentially, upon the policies expected to be served by a broad or narrow interpretation. Essentially, therefore, judicial characterization of searches as reasonable or unreasonable is a choice between policies; a determination between conflicting social interests. Yet almost never, in declaring a particular search unreasonable, do the courts reveal a consciousness that they are appraising alternative policies, nor do they expound the facts upon which evaluation might have been based. At best the opinions are but assertion of "rule", or adoption of precedent. 8

During the long years before Prohibition the question of reasonableness in search came but infrequently before the courts. The yearly average of cases was perhaps one-half of one per cent. of the yearly grist which began in I920. It was only with Prohibition that the rule precluding use of evidence obtained by unreasonable search sprang into general importance. It had existed as a rule in the federal courts since I9I4, at least; but state courts had looked at it askance and refused it approval. Hence, prior to Prohibition there was little to be gained by questioning the reasonableness of a search. If it had produced evidence of criminality on the part of the person whose privacy was invaded he found scant sympathy. He was himself a criminal, who ought to be punished, and that was that. If the search were

6. People v. Case, 220 Mich. 379, 386, I90 N. W. 289, 29 I (I922). "Neither our State or the Federal Constitution directly prohibit search and seizure without a warrant as is sometimes asserted. Only 'unreasonable' search and seizure is forbidden."

7. In some other fields of law, the problem of what is or is not "reasonable" is treated as a question of fact to be determined like other issues of fact by the jury. In a tort action, for example, the negligence of the defendant, i. e., the reasonableness of his conduct under the circumstances, is treated as a jury question even when the circumstances are not in dispute. "It is only when the facts are such that all reasonable men must draw the same conclusion from them, that the question of negligence is even considered as one of law for the court." Grand Trunk Ry. v. Ives, I44 U. S. 408, 4I7 (I892), quoted with approval in Fish v. Grand Trunk Western Ry., 275 Mich. 273, 275, 266 N. W. 349, 350 (I936).

The reasonableness of a mistake of fact seems also to be generally assumed to be a problem for the jury. "It is impossible to lay down any general rule. Each case must depend on its own nature and circumstances." Stern v. Georgia, 53 Ga. 229, 231 (I874). The writer finds no case in which the question has been taken from the jury by specific instructions, even when the surrounding circumstances have been undisputed. The determination of reasonableness of a search by the court instead of by the jury is probably explicable by the fact that the question usually comes up in relation to admissibility of evidence, in which connection questions of fact are commonly decided by the court itself.

8. In Carroll v. United States, 267 U. S. I32 (I924), the Court did give some consideration to the practical effect of one ruling or another, and thereby reached a conclusion that the search was reasonable. The decision is criticized by Black, $A$ Critique of the Carroll Case (r929) 29 CoL. L. REv. I068, and commended in Note (I925) 23 MrCH. L. REV. 89r. 
unreasonable, he had a legal right of direct action against the searcher, but no great reason for exercising the right. Law-abiding citizens, whose protests might have found both sympathy and effect, either seldom found their right of privacy unreasonably invaded, or did not take the intrusion seriously. At any rate one finds in appellate court records only an occasional case-a few civil actions for trespass, a criminal prosecution, ${ }^{9}$ a motion to vacate an order impounding property for use as evidence, ${ }^{10}$ the federal court cases and an attempt or two to introduce the federal rule into state courts.

Out of Prohibition, however, evolved two novel circumstances. With the enactment of the Prohibition law tens of thousands of erstwhile more or less law-abiding citizens became at least technical lawbreakers and exceedingly fearful of search, whether reasonable or otherwise. And sequentially if not consequently a score of state courts hastened to adopt the federal rule that evidence obtained through unreasonable search could not be used for conviction.

These state court adoptions of the federal rule demonstrate the same apparent failure to consider and expound the actualities of social necessities that is the thesis of this article. The first of the new development was People v. Marxhausen, ${ }^{11}$ begun in August of 19 I 8 under the then recent state prohibition law. The defendant owned a summer place in the Detroit River. In August, while the defendant himself was in South Carolina and his place unoccupied, a motley crew of enforcement agents consisting of five food and drug inspectors, a village marshal, a deputy sheriff and a justice of the peace, went to the island and searched the house, without a warrant. They presumably lacked also the consent of the defendant, although they appear to have gotten into the building without necessity for breaking door or window. They found illegally possessed liquor, which was impounded for use as evidence. On motion of the defendant the circuit court ordered the liquor returned to him before trial. On appeal by the state from this action, the supreme court approved it on the ground (a) that the search was unreasonable, and (b) that because it was unreasonable the liquor must be returned. Neither in setting up the premise (a), nor in drawing therefrom its by no means inescapable conclusion (b), does the judicial opinion advert to existing social conditions, social interests, social needs or any other facts suggestive of the utilities involved. Both premise and deduction therefrom are presented as the necessities of precedent, and nothing else. ${ }^{12}$

9. State v. Lathers, 3I Ark. 44 (I876).

Io. Newberry v. Carpenter, I07 Mich. 567,65 N. W. 530 (I895).

II. 204 Mich. 559, I7I N. W. 557 (I9I9).

12. Experienced newspapermen once characterized the writer as a cloistered innocent for not suspecting that the particular case might have been concocted by persons hostile to the law for the very purpose of getting an emotionally reactive appellate opinion that would hamper enforcement. 
Quickly following the Marxhausen case came a Kentucky decision. ${ }^{13}$ Here officers had gone to the residence of one Youman with a warrant for his arrest on a charge of violation of the state liquor laws. They could not find him, but they searched the house and did find evidence of his criminality, by the use of which he was convicted. In reversing the conviction the appellate court held, as in the Marxhausen case, first, that the search of the house was "unreasonable"; and second, in a lengthy opinion, that evidence obtained by unreasonable search should not have been received by the trial court. And again, both conclusions were predicated solely upon precedent and the opinions of text-writers as to the law, with no apparent inquiry as to whether or not existing social conditions made those precedents applicable.

These two new factors-the widespread antipathy to any search, reasonable or otherwise, and the sudden practical advantage of having a search declared unreasonable-gave cause for raising the question of reasonableness in the courts. At the same time, a tremendous increase in the number of searches made by police authority gave ample occasion for raising it. Cases requiring characterization of particular searches as reasonable or otherwise began to fill the books. In most cases the decision was a simple one of judicial reaction to the particular facts-reactions purely personal and widely variant.

But in some opinions the court laid down what might well be called "rules" of unreasonableness. And here again the rules were attributed to precedent without any apparent consideration of the suitability of those precedents to the more modern social conditions. The rules, as formulated, may or may not be sound; the writer does not herein dispute the wisdom of any of the decisions noted. What he does question is the process by which the courts arrived at those decisions-the expressed factors from which the judges drew their conclusions of what would be best for society.

In Fennemore v. Armstrong, ${ }^{14}$ for instance, the action was in trespass, plaintiff alleging that the defendant, without a warant, had searched his house for stolen chickens. The defendant was not a peace officer, though he had been accompanied by a constable, and the judicial declaration that the search was "unreasonable" might have been put on that ground. But Boyce, $\mathrm{J}$, simply instructed the jury as a matter of law-not leaving the question of reasonableness to them as a fact-that, "If a constable enters a dwelling house in the occupancy of another against the latter's will for the purpose of searching for stolen property without a warrant therefor, he is a trespasser and liable in damages to the person injured. . . . No amount of suspicion or incriminating evidence will justify any search of a residence for stolen goods without a search warrant having been issued to search that particular

I3. Youman v. Commonwealth, I89 Ky. I52, 224 S. W. 860 (I920).

I4. 29 Del. 35, 96 Atl. 204 (Super. Ct. I915). 
house, unless the occupant voluntarily consents thereto." 15 There was no weighing of the wisdom of "the law"; no questioning whether such was in truth the law, nor why; simply the assertion of a "rule".

Some years later, after Prohibition, in Agnello v. United States ${ }^{16}$ it appeared that police officers had arrested Agnello on charges of unlawfully possessing and selling cocaine. He had been seen by them to make a sale on the street and was promptly arrested. There was sound reason to suppose that he had taken what he sold from a larger supply concealed in his house. Had the police waited to get a warrant before searching the house, there is a strong probability that news of the arrest would have been carried to Agnello's associates and that all cocaine would have disappeared from its hiding place long before the police could have begun to look for it. As a mere matter of practicality the search was well advised. But as a matter of "law", the Supreme Court thought otherwise. Without adverting to the practical wisdom and the necessities of the particular case, it laid down the rule that "While the question has never been directly decided by this court, it has always been assumed that one's house cannot lawfully be searched without a search warrant, except as an incident to a lawful arrest therein." 17 It was a rule of "can not" that the court enunciated; not a decision of "was not". 18 Here, again, just as the court ignored the facts and the practicalities

I5. Id. at 38, 96 Atl. at 205. See also Gamble v. Keyes, 35 S. D. 644, I53 N. W. 888 (Igr5) (search made within a few hours after an arrest inside the house) ; Simpson v. McCaffrey, I3 Ohio 508 (I844).

I6. 269 U. S. 20 (I925).

I7. $I d$. at 32 .

I8. The narrowness of this rule caused an Oklahoma court some perturbation in a later case. In Wallace v. State, 42 Okla. Cr. I43, 275 Pac. 354 (I929), the defendant had been convicted of violating the liquor law and the court had followed the rule of the Agnello case literally, saying: "Here the evidence indicates the arrest was made in the road or street in front of the residence. . . . The right of search in case of arrest is of the person and immediate surroundings of the arrested person. It does not carry with it the right to search buildings and places other than the immediate surroundings of the person arrested." Id. at 144, 275 Pac. at 355 . Then, only four months later, a conviction of burglary was appealed to this same court. Patton v. State, 43 Okla. Cr. 436, 279 Pac. 694 (I929). It appeared that a number of burglaries had been committed. Suspecting defendant, officers had gone to his house to arrest him but failed to find him there. Later they went again and discovered him outside the house, about twenty feet from the door. Having arrested him there, outside the house, they searched the house, and the evidence obtained by the search was used despite defendant's protest at the trial. The appellate judge who had written the opinion in the Wallace case quoted what was said therein, then added: "Under these circumstances, the arrest of defendant was so connected with the dwelling house that the right of search existed." Id. at 439, 279 Pac. at 695.

The rule, as a rule, suggests also a somewhat amusing speculation in a Michigan decision, People v. Chimovitz, 237 Mich. 247, 2II N. W. 650 (I927). At one o'clock in the morning a police officer observed smoke in the defendant's store. "He called defendant, who came soon thereafter, but without keys. He went for them, and, returning, the store was opened. Defendant entered followed by police officers. Whether the officers entered with or without permission is disputed." Id. at 249 , 2II N. W. at 65 I. They found therein evidence of arson. On trial of defendant for setting fire to the building, he objected to use of the evidence as having been obtained by unreasonable search. The court held that the officers, with or without permission, entered rightfully to put out the fire, and being thus rightfully in the building, they reasonably made observations and took the evidence. One wonders, if they really entered, as the court said, "to put out the fire," through what neglect of duty they had let the fire burn unchecked while they got the defendant and he got the keys. 
of the particular situation, so it ignored-in utterance, at least-all the facts from which it determined the real utilitarian wisdom of the "rule" which it either "found" or created. Possibly the court relied, as it appeared to do, solely on precedent without regard to existing actualities; perhaps it weighed its own rather narrow definition of reasonableness in the scale of facts as the judges assumed them to be. But it was a cryptic test at best; one can do no more than speculate as to what those judicial assumptions might have been, and wonder how accurate in truth they were.

Even the expressed exception to the rule, the concession that search of a house without a warrant may be reasonable if immediately following a lawful arrest therein, ${ }^{19}$ has been considerably limited by judicial decisions that virtually lay down a rule of restriction. In a pre-Prohibition case ${ }^{20}$ the New York court said: "The police have the power and it is also their duty to search the person of one lawfully arrested, and also the room or place in which he is arrested, and also any other place to which they can get lawful access, for articles that may be used in evidence to prove the charge on which he is arrested. We have no statute defining this power or prescribing this duty, but the ends of justice require that they should exist, and they have been exercised under the common law from time immemorial. The authorities on this head seem to be few, but only because the thing has seldom if ever been questioned." 21 So also, in I9I4, the Michigan court held a house-wide search following an arrest for murder, to be reasonable, and relied in part upon the foregoing quotation. ${ }^{22}$

But, in a Prohibition case of $I 923,{ }^{23}$ the Michigan court asserted very definite limitation upon the extent of the search. Police officers acting under a warrant had lawfully arrested the defendant, inside her house, on a charge of maintaining a place where intoxicating liquor was "illegally possessed, sold, stored for sale, given away or furnished." They then searched the house and found a quantity of liquor concealed under the flooring at the top of a stairway. The use of this liquor in evidence was objected to by defendant and the appellate court held that the objection should have been sustained. Again it noted with approval the foregoing quotation from the New York court, but added the limitation that:

"In the instant case the sheriff had no search warrant; the warrant which he had was for the arrest of the defendant; it gave him lawful access only to that part of the house which it was necessary for him to

I9. United States v. Mills, I85 Fed. 318 (C. C. S. D. N. Y. I9II), writ of error dismissed sub nom. Wise v. Mills, 220 U. S. 549 (IgII) ; United States v. Welsh, 247 Fed. 239 (S. D. N. Y. I9I7) ; see Weeks v. United States, 232 U. S. 383, 392 (I914).

20. Smith v. Jerome, 47 Misc. 22, 93 N. Y. Supp. 202 (Sup. Ct. I905).

2I. Id. at 23, 93 N. Y. Supp. at 202.

22. People v. Cona, I8o Mich. 64I, I47 N. W. 525 (I9I4).

23. People v. Conway, 225 Mich. I52, I95 N. E. 679 (I923). 
enter to serve his warrant. Here, where he was lawfully present, he could search for evidence of the crime for which the arrest was made; but farther he could not go without invading the constitutional rights of the defendant. He and his officers did not gain lawful access to that part of the house where the white mule was kept. There they were trespassers." 24

Just what may reasonably be looked for when officers are reasonably making a search is a matter of some confusion in the decisions. The tendency, however, especially under the conditions of Prohibition enforcement, has clearly been to limit the search to evidence relating to the particular crime out of which the search originated. In United States $v . M i l l s,{ }^{25}$ for example, it appeared that following an arrest for conspiracy to defraud by evasion of customs duties, the marshal seized many books and papers of the defendant. All were returned to him, except some which tended to prove other criminal offenses on his part. He asked an order for the return of these also. This order was made, but it is not clear whether because of the illegality of the original seizure of all books and papers, or because the court thought search ought to be limited to evidence of the specific crime. ${ }^{26}$

Again, however, subsequent to Prohibition, the Michigan court went to an extreme. ${ }^{27}$ In 1923 a sheriff and his deputy entered a house under authority of a warrant authorizing them to search for stolen beans. They did not find the beans, but they did discover seven gallons of unlawfully possessed whiskey. The court held that entry of the house through this warrant to search for beans did not make reasonable the seizure of the liquor. "Except as he followed the strict mandate of his warrant to search for and seize, if found, a described quantity of beans, the officer was a trespasser upon those premises." 28

24. In respect to this limitation, however, the courts are not in agreement. In conflict with the limitation set by the Michigan court, see Sayers v. United States, 2 F. (2d) I46 (C. C. A. 9th, I924). "A lawfully arrested person may be searched for instruments, fruit, and evidences of the crime; and, if taken in commission of the crime in a building, the latter may be likewise searched to the extent that the offender's control and activities likely extend. This is the law since the Fourth Amendment, even as it was law before it, is reasonable, and is not within the amendment's ban upon unreasonable searches and seizures." Id. at I47. Accord: United States v. Charles, 8 F. (2d) 302 (N. D. Cal. I925) (liquor found in search for narcotics may be used in evidence); Marron v. United States, 8 F. (2d) 25 (C. C. A. 9th, I925) (private papers evidentiary of crime may be examined and used).

25. I85 Fed. 318 (C. C. S. D. N. Y. rgrr).

26. Accord: United States v. Mounday, 208 Fed. I86 (D. Kan. I913), showing the same lack of clarity as to the reason.

27. People v. Preuss, 225 Mich. 115, I95 N. W. 684 (1923).

28. Id. at I20, I95 N. W. at 686 . In a still later federal case, where the defendant had been arrested in his office, by virtue of a warrant charging conspiracy to violate the Prohibition Act, the officers searched the office for incriminating papers, a number of which were found. The circuit court of appeals, Swan, J., dissenting, ordered them returned to the defendant, saying:

"There are, however, certain fixed boundaries which may not be transgressed. One of these, and the only one we need to mention now, is the firmly rooted proposition that what are called general exploratory searches throughout premises and personal property are 
In every one of the cases discussed above, the court had power-and the right, so far as any philosophy of law known to this writer is concerned-to render a different decision. No definite rule established by precedent compelled the opinion rendered; no legislation required it; no immemorial custom, nor even a recent one, evinced its desirability. Each decision was the exercise of judicial option, predicable, had the court so desired, on appraisal of social needs and an evaluation of utilities. Had those courts deemed it wise, they could have laid down a general rule that a search is reasonable whenever the officer making it has reasonable ground to believe that he will discover evidence of criminality and reasonable ground to believe also that such evidence cannot be obtained by more dilatory or less drastic procedure.

Such a rule, within narrow limits, was in fact suggested by the Supreme Court itself in Carroll $v$. United States. ${ }^{29}$ The Court sustaining the reasonableness of search of an automobile without a warrant, as distinguished from similar search of a house, said:

"If an officer seizes an automobile or the liquor in it without a warrant and the facts as subsequently developed do not justify a judgment of condemnation and forfeiture, the officer may escape costs or a suit for damages by showing that he had reasonable or probable cause for the seizure. . . . The measure of legality of such a seizure is, therefore, that the seizing officer shall have reasonable or probable cause for believing that the automobile which he stops and seizes has contraband liquor therein which is being illegally transported. . . . Such a rule fulfils the guaranty of the Fourth Amendment. In cases where the securing of a warrant is reasonably practicable, it must be used. . . In cases where seizure is impossible except without warrant, the seizing officer acts unlawfully and at his peril unless he can show the court probable cause." 30

Such a rule of reasonableness, had other courts chosen to extend it to searches in general, might have been justified by analogy of the rule that an arrest by a peace officer is "reasonable" whenever the officer has reasonable ground to believe that the arrestee has committed a felony for which the arrest is made. And this finding of reasonableness in the arrest follows upon

forbidden. It does not matter whether the premises are comparatively large or small, whether the articles of personal property opened and the contents examined are numerous or few, the right of personal security, liberty and private property is violated if the search is general, for nothing specific, but for whatever the containers may hide from view, and is based only on the eagerness of officers to get hold of whatever evidence they may be able to bring to light." Lefkowitz v. United States Atty., 52 F. (2d) 52, 54 (C. C. A. 2d, I93I). The court "distinguishes" Marron v. United States, 275 U. S. I92 (1927) - which held that arresting officers were justified in searching a closet for liquor for which they had a warrant, and in seizing without a warrant a ledger book and papers-on the ground that those were "things openly displayed to view, picked up by the officers and taken away at the time an arrest was made." Ibid.

29. 267 U. S. I32 (I925).

30. Id. at I55. 
reasonable ground to believe the arrestee guilty, even though it might have been practicable for the officer to wait for a warrant.

Indeed, the courts in setting up rules for reasonableness of search had a third supportable choice. They might have laid down the rule that a search which proves the person searched to be guilty of crime is by that very fact shown to have been a search made in the public interest, and thereby becomes reasonable. ${ }^{31}$ And in justification of such a rule, they might have relied on the analogous opinions of legislators in at least seventeen states, whose statutes provide in effect that an arrest by a peace officer is lawful, i. e., reasonable, (a) if the officer has reasonable ground to believe the arrestee guilty of a felony, or (b) if the arrestee is in fact guilty. ${ }^{32}$ The courts might have declared this latter postulate as the wisest application of public policy, or they might have approved the narrower generalization suggested above. But for some unexpressed reasons of their own they preferred the still narrower rules exemplified in their decisions.

\section{As the writer has already said, it is no purpose of this discussion to con-} demn the rules of reasonableness adopted by the courts, even though criticism

3I. It would of course be an obvious error to assume that if a search which actually produces evidence of crime is held reasonable, searches which do not produce evidence will be encouraged; the liability for the latter will still remain, undiminished.

32. There is some doubt as to the constitutionality of such statutes, however. In People v. Case, 220 Mich. 379, 388, I90 N. W. 289, 292 (r922) the court said, as a matter of dictum, "The question whether a seizure or a search is unreasonable in the language of the Constitution is a judicial and not a legislative question. . . ."

An abortive attempt to get a judicial opinion on the point was made in People v. Stein, 265 Mich. 6I0, 25I N. W. 788 (I933). A state statute enacted in I927 [3 MICA. CoMrp. LAWS (I929) $\$$ I7I 49 (b) ] provides that an arrest by a peace officer shall be "lawful"--hence "reasonable" - when the person to be arrested "has committed a felony, although not in the presence of the officer." Inasmuch as other sections of the statute cover cases where an offense has in fact been committed and the officer has reasonable ground to believe so, the provision quoted is meaningless surplusage unless it be deemed to mean precisely what it says-that the arrest is lawful if the arrestee is in fact guilty, regardless of the officer's reasonableness of belief.

For six years this statute was ignored by police, prosecuting attorneys and judges. Then, the statute having been called to the attention of the Detroit police and prosecuting attorney, the Stein-Massie case was picked as an opportunity for testing its meaning and validity. Police officers in a scout car had observed Messrs. Stein and Massie riding in a taxicab. Suspecting these gentlemen as gun-toters, but concededly without what they could demonstrate to a court as reasonable ground for so believing, the police halted the taxi and searched its occupants. On Massie's person they found a revolver and on the seat behind Stein an automatic pistol which he had just taken from his pocket. The two were charged with carrying concealed weapons without a permit, a felony in Michigan. The examining magistrate refused to admit the weapons in evidence, on the ground that they had been obtained "by illegal arrest and search", and dismissed the prosecution. Yet clearly it was a "lawful" arrest and search under the statute, since the persons arrested were in fact guilty of the felony for which arrested.

The propriety of the magistrate's action was questioned in the supreme court. As the state had no right of appeal from the trial judge's opinion, the proceeding was in the form of application for a writ of mandamus "to compel the magistrate to reinstate the proceedings and receive the weapons in evidence." People v. Stein, supra, at 6rI, 25I N. W. at 789. But through some egregious oversight in the prosecuting attorney's office the existence of the statute was not so much as called to the supreme court's attention and the whole purpose of the proceeding was a failure. The trial court's action was approved on the strength of the existing judge-made rule that such an arrest was unlawful, without any mention of the stat- 
may be implicit in what is said about them, but only to comment on the process by which the courts appear to have made their choice of policies. The judicial opinions herein discussed are few in number and involve but a narrow field of social interest. In and of themselves they are of slight importance in the multiplicity of the country's problems. But in what they illustrate, they relate to a fundamental proposition of the greatest public magnitude. They raise a question whose ramifications reach into almost every aspect of social relationships which conflict of interest brings before the courts. The question is this:

Can it be either a sound philosophy of lawe or a wise social practice which permits judges, however learned and honest, to determine the social and economic policies of the country from the limited knowledge of social and economic needs produced by their ozen personal observations?

Yet that is precisely what judges appear to have done in respect to all sorts of cases in which a judicial choice between conflicting notions of wise public policy has been made. The particular decisions herein cited, concerning the clash between effective law enforcement and individual freedom from official molestation, are merely specific illustrations of judicial failure to ask for or receive information in addition to that of the judges' own empiricism. ${ }^{33}$

When Mr. Brandeis was acting as counsel in the case of Muller v. Oregon ${ }^{34}$ he set a notable example. Asserting that "the facts of common knowledge of which the court may take judicial notice" 35 showed how essentially reasonable and conducive to public good the disputed statute was, he nevertheless did not remain content with any assumed sufficiency of such judicial knowledge. Instead he proceeded cleverly and cogently to expound to the court many facts to which their empirical knowledge probably did not extend. But twenty years later, Mr. Justice Brandeis, in Olmstead v. United States, ${ }^{36}$ denounces a police method of obtaining evidence as "unreasonable" and not conducive to public good, with no request for information of condi-

ute. Nor, so far as the writer has discovered, have the similar statutes in other states been judicially passed on.

33. See the other illustrations suggested supra note I.

34. 208 U. S. 4 I2 (I908).

35. Id. at $4 \mathrm{I} 6$.

36. 277 U. S. 438 (I928). The Supreme Court's recent "wire-tapping" decision in Nardone v. United States, 58 Sup. Ct. 275 (I937), 86 U. of PA. L. Rev. 436 (I938) is recognized by both the majority and the dissent as purely one of "policy" in interpreting the federal statute. That statute provides that "no person" may properly intercept and divulge an interstate message. The majority opinion takes note of State v. Gorham, IIo Wash. 330, I88 Pac. 457 (1920), in which a municipal speed ordinance was interpreted as impliedly excepting police officers in performance of their duties from its literal terms, and recognizes the general rule that implicit exceptions of police officers may be, and often are, intended by legislatures. But it holds that as a matter of "policy" no such exception to the particular statute was intended. Justice Sutherland's dissenting opinion urges the practical necessities of effective law enforcement against criminals who use modern methods of communication, as a reason for inferring the exception. The majority opinion merely asserts its conclusion without expounding any utilitarian reasons, and with no indication of the assumed facts upon which it based its choice of policy. 
tions to which his own empiricism might not have extended and with no statement even of the "facts of common knowledge" on which his choice of policy was predicated. That it was a choice of policy his colleague Justice Holmes makes clear. "There is no body of precedents by which we are bound," he says, "and which confines us to logical deduction from established rules. Therefore we must consider the two objects of desire, both of which we can not have, and make up our minds which to choose." 37 But to choose on what basis of knowledge? Justice Holmes does not say.

It cannot be supposed that possibly illuminative information, information of wider scope than the casual observations of any judge, is unobtainable for use in determining what is reasonable. Whether additional facts would strengthen the judicial notions of proper policy, or alter them, is immaterial. The point is that to the extent that facts do exist they should be considered. And pertinent facts, capable of ascertainment but never adverted to in judicial opinions, do exist. For example, when the Olmstead case was before the courts, Chicago newspapers announced that the identity of certain train-robbers had been discovered because the police had listened in on telephone conversations between suspects. Eventually a number of those men were convicted-dangerous criminals eliminated, for a while, as menaces to society. But none of the evidence obtained by wire tapping was offered to the trial court. Instead, some of the lesser fry were persuaded to turn state's evidence, and conviction was based thereon. How they were persuaded does not appear; perhaps it was only by promise that they would not be secluded from society if they could help make sure that the other defendants would be; possibly it was by other means. In any case, some known criminals were freed so that others might be incarcerated. Why did the state's attorney follow this method instead of using the evidence obtained by wire tapping? Did he fear that the court would reject the evidence as "unreasonably" procured? If so, we have an evil springing from narrow definition of reasonableness that might well be contemplated by judges, if informed of its existence, in formulating their definition.

In another city, police officers themselves got into court as defendants because, instead of arresting the operator of a blind pig, they smashed his paraphernalia and the furnishings of his house. Thus there came to public knowledge a police practice of harassing out of business criminals whose suppression the public demanded but whose conviction the courts had made impracticable by narrow definition of reasonable search. The men who had smashed and destroyed acted under admitted orders from the departmental head-orders given for the accomplishment of a public purpose whose attainment in a more legal manner had been made impracticable by what must have

37. Olmstead v. United States, 277 U. S. 438, 470 (I928). 
seemed to the police closely cloistered judicial notions of public policy. ${ }^{38} \mathrm{Per}$ haps such knowledge, too-realization by the judges of the probable actual effect of their decisions-might have affected their ideas of wise public policy, had they possessed the knowledge.

In the Olmstead case Justice Holmes thought it "a less evil that some criminals should escape than that the government should play an ignoble part." 39 Passing over the question of distinction between what is ignoble and what is pragmatically wise, did Mr. Holmes know how many criminals do in fact escape because of the narrowness with which courts choose to define reasonableness? Possibly definitions might be broadened if judges knew that. The number runs into thousands, though how many thousands the writer does not know. In the City of Detroit alone, a cursory investigation revealed the fact that during a single year thirty-eight indubitably guilty carriers of concealed weapons, a felony punishable by five years imprisonment, were turned loose on society by the courts-and many more by the police-solely because the courts did not approve as reasonable the manner in which the arrest and subsequent search had been made. That was a period when armed robbery, assault, and murder were rife in the city, yet the investigation indicates that one out of every four gunmen arrested was released, by the courts or by the police themselves, because the courts' ideas of reasonableness differed from those of the police. ${ }^{40}$ So great became the scandal that the people of the state eventually cut the ground from under the judicial rulings by altering their constitution. ${ }^{41}$

All this is no more than the modicum of information that has come casually to this writer's knowledge. How much more there is to know, he has no idea; but obviously there must be more, much more. It stands out as a matter of reason that there must be many things in fact undreamed of in

38. For newspaper commentary on the situation, see the Detroit Saturday Night, Nov. 22, I930, P. II, col. 2.

39. Olmstead v. United States, 277 U. S. 438 , 470 (I928).

40. The matter is more fully discussed in Waite, Public Policy and the Arrest of Felons (1933) 3I MICH. L. REv. 749.

4r. Amendment proposed by legislature of 1935 ; ratified at general election, November, I936; Mich. Acts I937, p. 876. The alteration as drafted by its sponsors is somewhat peculiarly worded and is limited, incomprehensibly enough, to cases of carrying concealed weapons. The amendment provides that the search and seizure provisions of the constitution "shall not be construed to bar from evidence in any court of criminal jurisdiction or in any criminal proceeding held before any magistrate or justice of the peace, any firearms, rifle, pistol, revolver, automatic pistol, machine-gun, bomb, bomb-shell, explosive, blackjack, slungshot, billy, metallic knuckle, gas ejecting device, or any other dangerous weapon or thing, seized by any police officer outside the curtilage of any dwelling house in the state." Although the draftsman of this amendment seems to have made a wide category of utensils admissible in evidence, it will be noted that proof of larceny, of burglary, of murder, or of any other crime, is still not admissible though obtained at the same time and in the same manner as the weapon. Gun-toters can be convicted, but not gun-users. The obvious failure of this amendment to meet the social needs which it implicitly recognizes indicates the difficulty of dealing with the problem by constitutional change. As a practical matter, whatever is done for public protection must be done by the courts. 
the empirical philosophy of even supreme court judges. Yet "knowledge is essential to understanding and understanding should precede judging." 42

Why, then, have judges not asked for, or been offered, that essential information? Perhaps because the tradition still persists that courts find law, but do not make it. "Government by law" presupposes "rule", transcendent of judicial will. Determination of controversy by judicial predilection has always been an anathema in our idealism; guidance by something extraneous to a judge's whim is still insisted on as a postulate. Even those who urge that judicial decision be utilitarian recognize certainty, predictability, external guidance - and, therefore, the value of precedent-as prime among the utilities. The tradition of history, of analysis, of logic as the only guides, the cliché of some precise and transcendent extraneous determinant of decision, still permeates our speech and is used to rationalize our actions. Hence, if one be traditionally minded, what is "reasonable" is not what is utile, but is-is what? How can it be anything else? In truth, what is reasonable can be nothing more nor less than judicial notions of what is wise policy. But it is possible that in formulating their ideas of what is wise, judges have felt that so long as conventional philosophy persists in denial that they exercise a power of choice, they cannot properly invite a presentation of information on which to predicate their choice.

One other, less philosophical, more practical, reason for the judicial neglect of facts may be the difficulty of gathering reliable data. For a decade at least, students in the better law schools have been taught that the utilities do affect judicial decision; that analogy and logical analysis are not the only guides to prediction. One might expect men so trained to offer to courts, without invitation, information of actual conditions and social needs, as $\mathrm{Mr}$. Brandeis did in Muller $v$. Oregon. But who is to gather that data? In the ordinary case, counsel do not have time, nor their clients the money. So far' as the reasonableness of search is concerned when the question is raised in a criminal case, the prosecuting attorney is seldom in a position to go deeply into research, and defense counsel are satisfied with the decisions as rendered. Some law teacher may eventually hunt out the facts, but to do so will take money as well as time; with neither of which commodities are law teachers abundantly supplied. ${ }^{43}$

42. Burns Baking Co. v. Bryan, 264 U. S. 504, 520 (1924). Mr. Brandeis is, of course, not the only judge who has recognized and asserted the judicial need for real knowledge of the facts of social life. See, for instance, CARDOzo, THE GROWTH OF THE LAW (Ig24) II7, ". . . there is a constantly increasing need for resort by the judges to some fact-finding agency which will substitute exact knowledge of factual conditions for conjecture and impression."

43. One must recognize also the technical difficulty of getting the pertinent information before the courts. Shall it come in without controversy, by stipulation? But to what extent would parties agree on social and economic conditions without dispute? Or shall each side be heard as to its own allegations of fact? And in that case shall asseverants be subject to crossexamination? The writer cannot answer such questions. Yet to say that the legal profession 
Possibly there is no remedy, and "utility" must still be left to determination out of empirical judicial knowledge. But perhaps, on the contrary, much can be done, and will be done eventually, by organized research activityby the great moneyed foundations, by chambers of commerce, by the American Law Institute and by the law schools. ${ }^{44}$ The latter have already changed the character of their education. The older notions of instruction solely in precedent, analysis and analogy have given place to frank exposition of utilitarianism as one of the influences upon judicial decision. Law schools long ago, as a part of their educational function, took the lead in investigation of principle and precedent as guides to decision. Now that they so clearly recognize utility as an added influence, may not the public expect of them leadership also in collection and study of data from which the utilities can be determined?

One thing is certain; whenever data which indicate the wisdom of one public policy or another are known to be available, courts will invite their presentation, or lawyers will offer them uninvited for judicial consideration. And when some law school or other institution does contemplate research into the socio-economic background of a policy problem to be settled by judicial decision, the writer ventures to hope that the true "reasonableness" of searches for evidence of crime will be considered.

could not answer them would be a defeatist attitude in which the writer could not acquiesce. If the problem of presentation cannot be answered, then, of course, judges will have no alternative save to choose policies which to their own observances seem the best. There will be no need for anyone to collect data because the data cannot be used. And in that case this whole discussion is pointless. But the writer believes that the problem can be solved by lawyers and judges when they set their minds to it.

44. This is not a novel idea. Some years ago, Dean Henry M. Bates, in an address to the Nebraska state bar association, suggested that:

". . both the bench and the bar are overwhelmed with the necessities of law business and the adjudication of present cases, and have not the time or strength or point of view necessary to enable them to make those researches in the juristic field from which alone sound development may come. Why should not a few of our stronger law schools, and perhaps especially some of those connected with the state universities, enter the field which we have explored this afternoon? A legal research bureau established in connection with such schools might conduct researches in the legal and economic or other fields concerned in legislation under review by the courts, and upon request or suggestion of the court furnish valuable studies to those tribunals in the performance of their delicate and difficult task. Such a bureau should be composed of lawyers trained in the work of investigation, and their staff should include economists, sociologists, accountants and statisticians, to investigate whatever province of knowledge may be indicated in relation to the matter before the court." Bates, The Courts and Unconstitutional Legislation, a Suggested Aid in the Work of Judicial Review (I926) 5 NEB. L. BULL. IOI, II8. 